5-1-2015

\title{
'Toxification' as a more precise early warning sign for genocide than dehumanization? An emerging research agenda
}

Rhiannon S. Neilsen

University of Queensland

Follow this and additional works at: https://digitalcommons.usf.edu/gsp

\section{Recommended Citation}

Neilsen, Rhiannon S. (2015) "'Toxification' as a more precise early warning sign for genocide than dehumanization? An emerging research agenda," Genocide Studies and Prevention: An International Journal: Vol. 9: Iss. 1: 83-95.

DOI:

http://dx.doi.org/10.5038/1911-9933.9.1.1277

Available at: https://digitalcommons.usf.edu/gsp/vol9/iss1/9

This Articles is brought to you for free and open access by the Open Access Journals at Digital Commons @ University of South Florida. It has been accepted for inclusion in Genocide Studies and Prevention: An International Journal by an authorized editor of Digital Commons @ University of South Florida. For more information, please contact digitalcommons@usf.edu. 


\section{'Toxification' as a more precise early warning sign for genocide than dehumanization? An emerging research agenda}

\section{Acknowledgements}

I would like to thank Stephen McLoughlin for his immeasurable guidance throughout the development of this paper. I would also like to thank my two most important and special supporters, Paul and Corinne Neilsen, for their unwavering commitment to me and 'toxification'. This paper was presented at the eleventh annual International Association of Genocide Scholars conference in Winnipeg, Canada in July 2014. 


\title{
"Toxification" as a More Precise Early Warning Sign for Genocide Than Dehumanization? An Emerging Research Agenda
}

\author{
Rhiannon S. Neilsen \\ University of Queensland \\ Brisbane, Australia
}

\begin{abstract}
In genocide scholarship, dehumanization is often considered to be an alarming early warning sign for mass systematic killing. Yet, within broader research, dehumanization is found to exist in a variety of instances that do not lead to aggression or violence. This disparity suggests that while dehumanization is an important part of the genocidal process, it is too imprecise as a salient early warning sign. Genocide scholars have acknowledged such a conjecture in the past. This article initiates an embryonic research agenda that offers "toxification" as a more precise early warning sign for genocide than dehumanization. It contends that while dehumanization signals that killing members of a particular group may be regarded as permissible, a more indicative early warning is one that flags when extermination is considered a necessity. Following a literature review of dehumanization, the purpose of this article is to introduce the idea of "toxification", and to illustrate how the concept can work in practice, using two twentieth century genocides as examples.
\end{abstract}

Keywords: peace and conflict studies, race and ethnicity, social psychology and interaction

\section{Introduction}

Scholarship over the last half century suggests that genocide does not manifest without hideously vivid preliminaries: the processes' paradox of contextual uniqueness and "painful axiom of invariance ${ }^{\prime 1}$ has yielded a number of early warning indicators that are considered common to genocides. ${ }^{2}$ Dehumanization - the denial of a person's humanity and his/her ejection from the "sphere of equal moral standing" 3 - is often accepted as an important early warning sign for genocide and mass atrocities. This is because it is a psychological-coping device for would-be perpetrators to commit acts that are axiomatically considered immoral, and internalised as exceptionally ethically affronting. However, outside the field of genocide studies, dehumanization is found to exist in instances that are not linked to aggression, conflict, or even violence; in fact, recent research has identified dehumanization in subtle, everyday social perception and common interaction. ${ }^{4}$ Such an incongruity calls into question the validity of dehumanization as a salient early warning sign for genocide. ${ }^{5}$ This is not to refute dehumanization's role in preparing perpetrators and populations for genocide to occur, but that genocide early warning frameworks need to identify a more pernicious process specific to genocide. Importantly, and to their credit, such an observation has been made by genocide scholars in the past, and thus reinforces the argument made here for a more precise early warning. However, within genocide literature, there remains little distinction between identifying when killing is regarded by the perpetrators as more allowable or tolerable because individuals are no longer included in the perpetrators' sphere of moral standing (as per dehumanization), and when extermination is regarded by the perpetrators as an absolute necessity - the latter, I contend, being more definite to genocide. Consequently, this article constitutes an embryonic research agenda that offers "toxification" as a contender for this more exact early warning. Toxification is the cognitive perception of victims as malignant and carcinogenic pests that must be purged for the survival of the perpetrator, and/or the perpetrators' ideal society. While toxification and dehumanization co-morbid, the former is distinct insofar that victims are perceived to be not only outside the perpetrators' human universe of moral obligation, but as irreconcilably lethal and therefore (in the eyes of the perpetrators) unavoidably exterminable. The observation that perpetrators regard the victims as toxic or fatal prior to extermination is not an anomaly in genocide research: indeed, kill or be killed rhetoric is largely cited. Yet, the operationalization of such a concept as an important early warning sign for genocide is largely absent; if anything, this perception of lethality continues to be erroneously regarded as dehumanization in current early warning frameworks. ${ }^{6}$ The purpose of this article is to offer an emerging conceptual agenda that introduces toxification as possible candidate for a more precise early warning sign for further robust empirical studies: I am not 
claiming with any conviction here that toxification is a more telling indicator. Such a claim would require greater empirical breadth that comparatively analyzes toxification in genocide vs. nongenocides-something better suited to future research once the need for a more telling indicator is recognized, and the concept is better understood. ${ }^{7}$ Hence, my inclusion of the Holocaust and the Rwandan genocide is to simply illustrate how toxification's two strains manifest. Further, I am not offering toxification as a cause for genocide: while this would be an interesting exercise, it would demand a different investigation entirely. ${ }^{8}$

This article begins with a literature review of dehumanization in genocide literature and broader dehumanization literature to illustrate its limitations as an early warning sign. Next, because this is essentially a theoretical conjecture - albeit in its nascent conception-I will engage with existing social theories regarding the abject and pollution, before providing a thorough explanation of toxification. Lastly, in seeking to avoid definitive claims that toxification is a more telling early warning sign for genocide, I look to the Holocaust and the Rwandan genocide of 1994 to illustrate how toxification manifests prior to and during genocide. To demonstrate that toxification is not simply specific to these cases, brief consideration will be given to an additional two twentieth century genocides. ${ }^{9}$

\section{Dehumanization}

The definition of dehumanization is consistent in genocide literature and broader dehumanization literature. Dehumanization is understood as the denial of an individual's essential humanness and identity, and thereby situating individuals "outside the boundary in which moral values, rules, and considerations of fairness apply"10 to other humans. ${ }^{11}$ It is the "psychological-symbolic removal of others from the classification of human"12 wherein the other is expelled from what Helen Fein termed the "human universe of moral obligation."13 An individual is no longer included in the moral compact to be responsible for the other or in the meaningful social fabric that "governs human relationships."14 Moreover, there are two main ways individuals are thought to be dehumanized: via the denial of human uniqueness (emotions that are felt only humans) and via human nature (emotions felt by humans and animals). ${ }^{15}$ The first is often understood as animalistic dehumanization, which refers to the denial of "uniquely human attributes,"16 such as moral sensibility, reason, emotional depth, and civility. Instead, the dehumanized is regarded as the antithesis of such qualities: coarse, immoral, impulsive, child-like, uncultured and governed by the satisfaction of basic needs. ${ }^{17}$ The second is mechanistic dehumanization, which is the denial of human nature, wherein the individual is regarded as incapable of empathy, vitality, warmth; rather, the individual is - like a machine-an insentient being, impervious to pain and passion as humans understand it. Thus, despite emphasizing different characteristics, both forms of dehumanization deny individuals their humanity, individuality and identity. ${ }^{18}$ Whereas the latter sees the individual as unable to experience - to "feel pleasure and pain"19 as a human would, the former sees individuals without agency-the capacity to "plan, intend and exert choice" 20 as a human would: in both instances the dehumanized are underserving of being in the universe of human moral obligation. ${ }^{21}$ Dehumanization is thus an estranging and othering process: it is the "activity of repressing, subjugating, annihilating the similarities between the self and others, and the ways in which the other is known and understood." ${ }^{22}$ Such a decommissioning of humanity causes individuals to treat others as "a means to an end, rather than an end in themselves." 23 Thus, whether writing about genocide or other processes, scholars accept a consistent definition of dehumanization. Yet, while there is a trend in genocide studies to regard dehumanization as a telling early warning indicator for mass slaughter, this same understanding of dehumanization is cited in other, seemingly banal processes in broader literature. Some genocide scholars have acknowledged the insufficiency of dehumanization as a telling early warning sign-as explored below-however, little movement has been made toward operationalizing a better concept. This disparity is explored below.

\section{Dehumanization in Genocide Literature and Broader Literature}

In genocide literature, dehumanization is often considered an alarming early warning sign for genocide, because it silences perpetrators' and the population's "universal human abhorrence of 
murder, ${ }^{24}$ because the targeted group victim is no longer seen as human. ${ }^{25}$ For instance, Gregory Stanton, in his celebrated Eight (now Ten) Stages of Genocide, regards dehumanization as the very "phase where the death spiral of genocide begins." 26 Similarly, Jacques Sémelin asserts that "killing starts with the words disqualifying [the victims'] humanity" 27 because it is thought to dull moral inhibitions against butchery. In his concluding analysis, Alexander Hinton cites essentialization - the marking and crystallization of difference-that sees the other as less than fully human as a "hallmark of genocide", because individuals are "depicted as legitimate targets of violence whose execution should not pose a moral dilemma. Killing them is not murder, but rather the slaughter of a lowly animal." 28 More recently, on the $9^{\text {th }}$ of December 2014, marking the $66^{\text {th }}$ anniversary of signing the 1948 Genocide Convention, the United Nations SecretaryGeneral's Special Adviser on the Prevention of Genocide Mr Adama Dieng remarked: "The Holocaust did not start with the gas chambers and the Rwandan genocide did not start with the slayings. It started with the dehumanization of a specific group of persons." ${ }^{29}$ Outside the purview of genocide literature, ${ }^{30}$ however, dehumanization is not associated with mass murder, ethnic cleansing, forced displacement or other crimes against humanity, nor is it loaded with such severe connotations. ${ }^{31}$

For instance, Nick Haslam et al. found that dehumanization exists in "everyday social perception, and can occur in the absence of intense conflict or aggression," ${ }^{\prime 2}$ such as the experiences of "women, immigrants, refugees, the homeless, African Americans and other stigmatised groups." ${ }^{33}$ Similarly, Laurie Rudman and Kris Mescher write about dehumanization of women by men, wherein women are often seen as instruments or tools, lacking agency, self-determination, and subjectivity: women are thus regarded as fungible, controllable and/or synonymous to animals. ${ }^{34}$ Using neuroimaging data of Princeton University undergraduate students, Fiske and Lasana Harris found that extreme out groups, such as poor people, the homeless, and drug addicts, were dehumanized to such an extent that they did not register in the participants' medial frontal cortex (the region of the brain responsible for recognizing and attributing a mental presence to others) as social beings. ${ }^{35}$ Dehumanization occurs in the event of physical difference; that is, if an individual is noticeably physically handicapped or suffering from mental disability that manifests physically. ${ }^{36}$ Heather Keith and Kenneth Keith ${ }^{37}$ unveil that people with physical and mental disabilities are frequently dehumanised in contemporary societies, and Phillip Goff et al. identify that Blacks are still thought by sects of contemporary America as positioned "somewhere between the deformed and the simian." ${ }^{\prime 38}$ A number of scholars have conducted various investigations into the dehumanization of refugees, asylum seekers, internally displaced peoples, and immigrantsall of whom experience dehumanizing policies, but are not destroyed en masse with the intention of total annihilation as per genocide. ${ }^{39}$ Lastly, further distancing dehumanization from genocide, Haslam et al. have argued that "merely being associated with animals or machines, or being denied the corresponding humanness traits or emotions, does not necessarily have negative consequences" ${ }^{40}$ because it apparently enables leaders to make difficult decisions concerning sanctioning strikes that could result in the death of civilians during warfare. Although the aforementioned groups face virulent prejudice, persecution, and often violence as a result of their dehumanization, ${ }^{41}$ there is little to no concern for genocide. ${ }^{42}$ Thus, while genocide rarely occurs in the absence of dehumanization, this literature review unveils that genocide does not begin with dehumanization, and that its usefulness as a telling early warning device can be contested.

Some genocide scholars have acknowledged the insufficiency of dehumanization as a telling early warning, and this serves to reinforce the argument made here for a more accurate indicator. ${ }^{43}$ Rowan Savage writes that "dehumanization is found outside the field of genocide studies," ${ }^{44}$ and that "dehumanization facilitates genocide, but no means causes massacre, or always has massacre as a result." 45 In a parallel vein, James Waller identifies that something more malevolent than dehumanization must flag the intention to destroy an entire group of people. ${ }^{46}$ Israel Charny maintains that, "the process that makes genocide possible does not stop at dehumanization... what needs to be added is to justify taking people's lives...the proof that the other is also a terrible threat to our lives and it is their intent to take our lives away from us unless we stop them." ${ }^{47}$ Lastly, Johannes Lang observes that "dehumanization leaves only a void"48 -it does not necessitate action, but rather allows for a space of possibility. Thus, in addition to the above literature review that points 
to dehumanization's limitation as an early warning sign for genocide, what is needed is a specific discussion regarding why this is the case: that is, what dehumanization does, and does not, signal.

Crucially, dehumanization says nothing to the perception of killing a certain group being a necessity. I submit that this is perhaps why dehumanization is seldom loaded with the same alarm outside of genocide literature: dehumanization does not necessitate an individual's mistreatment, abuse, or murder, but simply renders it more tolerable in the eyes of the dehumanizer. I contend that such misplaced emphasis on dehumanization-correctly identified by previous genocide scholars-is due to the blurring of the permissibility of violence and killing (as enabled and signalled by dehumanization), with an apparent imperative to kill. This is not to contest that dehumanization is an important part of the genocidal process; rather, that existing genocide early warning frameworks largely fail to distinguish between an allowable action, and a requisite action. Indeed, it is reasonable to conceptualize dehumanization as having degrees, ${ }^{49}$ yet even in its most absolute form where the individual is considered to be fundamentally inhuman and ejected from the sphere of equal moral standing, dehumanization still does not necessitate killing. This would then lend a thought process to whether there can be variants of dehumanization; however, even if this early warning is assigned a status of dehumanization variant, or belonging to the family of dehumanization, a novel concept that speaks directly to when killing is seen as a necessity in genocide is still required. Thus, there is space for developing such an early warning. In opening this research agenda, I propose the concept of toxification-a concept that eclipses the perception of victims as simply inhuman, and flags that perpetrators see the victims' destruction as a necessity.

\section{An Emerging Research Agenda: Toxification and an Engagement with Social Theory}

By way of engaging with Mary Douglas' social theory regarding pollution and Julia Kristeva's the abject, this section offer an embryonic conceptual framework that articulates when perpetrators believe the complete elimination of a targeted group is a necessity. According to Kristeva, the abject refers to the response to the blurring or loss of identity between the self and the other. While the actor of the ethic must be engaged in the "perpetual undoing of the said"50 and "must of necessity be ready to be afflicted by the performance of the other," stranger which unsettles, disrupts and disturbs oneself. ${ }^{52}$ Once the meaningful difference between the self and the other disintegrates, and the self is no longer recognizable as distinct against that which its own identity is forged, Kristeva states that the human reaction is typically of horror, exile, and disgust. ${ }^{53}$ While this conceptualization is helpful in explaining genocide perpetrators' and populations' reactions to certain groups, it sits uncomfortably with the idea of dehumanization that clearly articulates the difference between us and them: we are human; they are not. Nevertheless, Kristeva's analysis highlight that fear, horror and disgust are important to and disgust, and by extension, often warrant an attempt to distance oneself from the source of that makes one's identity uncertain.

Douglas' analysis of pollution is helpful for understanding genocide early warning signs, because it sheds light on the relationship between order and disorder within a pre-conceived system of "tidily organized" 54 ideas and values, and the way in which dirt and uncleanliness is thought to assault this uniformity. According to Douglas, "dirt is essentially disorder;" 55 thus, if a group is regarded as polluting a society, then they are seen to be spoiling patterns that a group wishes to preserve or achieve. So, it is understandable that there is a perceived necessity to remove such contaminating elements so as to maintain (or achieve) consistency. ${ }^{56}$ However, while concepts such as hygiene, dirt and uncleanliness do incite a yuk response and warrant a degree of urgency, they do not speak to life and death situations. I submit that would-be targets for genocide are regarded by the perpetrators to be more than simply a "matter out of place" ${ }^{17}$ - something that offends order and stimulates a desire to re-negotiate patterns of existence to ensure uniformity, or "positively re-ordering our environment, making it conform to an idea," 58 therein giving "form to formlessness." ${ }^{59}$ This paper builds atop of these ideas of contamination and pollution that spoils patterns to offer a concept that requires the specific response of extermination in the context of genocide: toxification.

Toxification is the cognitive perception of the target group as fundamentally lethal to the furtherance of the perpetrators' survival and society: the group is perceived to be not simply 
inhuman or inferior, as with dehumanization, but as a toxic presence that must be cauterized and destroyed. This noxiousness is regarded as irreconcilable, immutable and inextricable, and so cannot be remedied by any means other than extermination: essentially, toxicity incarnate. ${ }^{60}$ Owing to this, slaughter is necessarily extended to women and children: "Kill and scalp all, little and big... Nits make lice." ${ }^{61}$ The term toxic is used not to refer specifically to quasi-medical terminology, but to emphasize its irremediable status.

I offer toxification as the early warning sign that could better signal the onset of genocide than dehumanization. This is because it signals the stimulation of two of the most fundamental and entwined human emotions among would-be perpetrators: fear, and the survival instinct. The perpetrator's existence is held as a zero-sum game, wherein it can only be guaranteed at the expense of the victims'. Massacre becomes analogous to self-preservation, and killing blurs with purifying, sanitising and disinfecting a society of a mortiferious infection. ${ }^{62}$ Toxification flags that the perpetrators see genocide as a logical and just method of guaranteeing survival undertaken "by an innocent and injured party." ${ }^{63}$ As aptly put by Straus, "particular circumstances can cause people to commit harm they might not otherwise have been predisposed to commit" ${ }^{\prime 64}-\mathrm{I}$ propose that toxification could be the early warning sign that signals such a manipulation of individuals' perception of self-defence.

There are two strains of toxification identifiable prior to genocide. First, the victim group is conceived to be toxic to the ideal; that is, toxic to the furtherance of human civilization, the perpetrators' ideational reality or utopia, or the body politic. ${ }^{65}$ Victims are portrayed as poisonous deformations in society, the image of human progression, or as infectious contagions in the body politic of the perpetrators. The body politic refers to the unification and embodiment of the nation's sovereignty and people in common will and blood: that which affects the body politic, affects its people. ${ }^{66}$ For instance, medical rhetoric, metaphors and discourse encompassing pathology, terminal cancerous growths, blood-sucking parasites, diseases, viruses, bacilli, leprosy, syphilis, tuberculosis and microbes used to describe the victim group is demonstrative of such toxification. It is this process, whereby victims are branded as necessarily fatal and equaling death for the body politic and/or the perpetrators' society and future that signals the need for extermination. ${ }^{67}$ In this instance, toxification propagated in the form of toxic to the ideal rests more with abstract conceptualizations of survival. Second, the victims are depicted as toxic to the self: the perpetrators become convinced that the victims will, without fail and given the chance, murder the perpetrators. As aforesaid, victims are immune to persuasion, reason, or affection, and so cannot be reconciledextermination becomes seen as the perpetrators' only option. Toxification in the form of toxic to the self signals that perpetrators subscribe to a kill before being killed zero-sum logic. Thus, unlike toxic to the ideal, death is not abstract, and the collective is not toxic to the furtherance of a utopia; instead, perpetrators are genuinely convinced that they themselves and their families will be annihilated if no action is taken against the target group.

It is important to note that research noting the perceived lethality or toxicity of genocide victims is not sparse; in fact, the identification of victims being dangerous or lethal to the perpetrators is prolific in genocide literature, and serves to reinforce the need for an early warning sign that coherently speaks to this observation, such as toxification. ${ }^{68}$ Therefore, as an emerging research agenda, priority here rests with illustrating how toxification operationalizes to give the reader a better grasp of how the concept can be understood in practice. To do so, the next sections turn to the Holocaust and the Rwandan genocide of 1994 as examples of toxification, and how it is distinct from dehumanization.

\section{The Holocaust: Illustrating Toxic to the Ideal}

The purpose of looking to the Holocaust is to illustrate the toxification strain toxic to the ideal; specifically, with its focus on the body politic, the Aryan utopia and the irreconcilable and inevitable lethality the Jewish population was thought to pose to the Third Reich. ${ }^{69}$ The dehumanization of the Jewish population allowed for policies of discrimination, bigotry and prejudice as early as the 1920s. Yet, closer to the Final Solution, such rhetoric and cognitive perceptions of Jewish people began to incorporate assignments of toxicity, most notably as nocuous maladies to the German Volkskörper and the Third Reich. The Nazi ideology affirmed that the Aryan is the Prometheus 
of mankind, and that any individuals who fell foul of this model-such as Jews, Gypsies, Slavs, Poles, homosexuals, hereditarily determined a-socials, and the mentally and physically deficient (that is, people suffering from: congenital feeblemindedness, schizophrenia, severe hereditary physical deformity, severe alcoholism on a discretionary basis, hereditary blindness and manic depression ${ }^{70}$ - constituted nefarious and noxious obstructions to achieving an ideational utopia. ${ }^{71}$ Propaganda disseminated by the Nazi regime ${ }^{72}$ sought to convince the German ${ }^{73}$ population that preserving the fehlerhaften und defekten (deficient and defective) and the degenerate and depraved was to allow false humanity to intoxicate the Aryan ideal. ${ }^{74}$ For instance, Adolf Hitler cited fictitious "historical evidence...[which] shows with terrifying clarity, that in every mingling of Aryan blood (Blutsvermengung des Ariers) with that of lower peoples, the result was always the end of the cultured people." 75 Similarly, and further illustrating how toxification can be understood in practice, Jewish people were depicted in Nazi propaganda as subversive spongers penetrating the Blutkreislauf unseres Volkes (the bloodstream of our people). ${ }^{76}$ Jewish people were regarded as the Erkrankung von Volkskörper (disease of the body politic), the Volkerparasit (parasite of the people), and Die Sünden wider das Blut (the sin against the blood), corroding the body politic. ${ }^{77}$ That is, Jewish people were seen as not simply inhuman, but as "maggots feeding on a rotting corpse, the parasites that had to be surgically removed...a plague worse than the Black Death, the sponger who spreads like a noxious bacillus and then kills his host." ${ }^{18}$ Likewise, the infamous child storybook Der Giftpilz (The Poisonous Mushroom), wherein Jews are described as poisonous mushrooms and the "incarnation of everything evil and soulless"79 is also an illustration of toxification. ${ }^{80}$ These examples of discourse prior to and during the Holocaust are loaded with connotations that clearly transgress the line of regarding individuals as inhuman and existing outside the sphere of equal moral standing; rather, victims were regarded by the perpetrators as being toxic and fundamentally lethal. ${ }^{81}$ By extension, then, the recognition of an entity being toxic introduces an element of necessity to get rid of that which poses an irreconcilable threat. ${ }^{82}$ Fritz Klein, a physician at the Auschwitz concentration camp, reported that just as he would "remove a gangrenous appendix from a diseased body" he removed Jews "as gangrenous appendix in the body of mankind." 83 By this, Klein saw the extermination of the Jewish people "as a therapeutic imperative [out of] respect for human life." ${ }^{84}$ During the genocide, and reflecting on the systematic carnage of the Jew people, Heinrich Himmler, Reichsführer of the Schutzstaffel (SS), stated that, "we [speaking on behalf of the German people] have stayed decent...we have suffered no harm to our inner being, our soul, our character." ${ }^{\prime 85}$ These reports shed light on the perspective of annihilation of the Jewish race as a necessity because of their apparent toxicity. The purpose of looking at the Holocaust was to demonstrate how toxification as toxic to the ideal could be understood in practice. It highlighted that there is a distinction between regarding individuals as underserving of being included in the human universe of moral obligation, and regarding them as something toxic or lethal that necessitates their extermination - the latter, despite being recognized in genocide literature, is often overlooked as a useful early warning sign distinct from dehumanization. While the Holocaust illustrates toxic to the ideal, the Rwandan genocide can be looked to as an example of toxification as toxic to the self.

\section{The Rwandan Genocide: Illustrating Toxic to the Self}

In 1994, via the medium of Kangura, broadcasts from Radio Rwanda, and community meetings, Tutsis were labelled inyenzi (cockroaches), ibinhindugemb (heinous monsters without a head or tail), and devils, which consumed the organs and innards of Hutus. ${ }^{86}$ Although this initially appears to be dehumanization, the labels are loaded with toxic and lethal connotations. For instance, a cockroach is not just inhuman: cockroaches are disease-disseminating agents, which hoard and transfer illnesses that are lethal to humans, such as salmonella, staphylococcus and streptococcus. Similarly, such use of the terms monsters, demons or devils suggests that Tutsis were regarded as not simply inhuman entities to be excluded from the sphere of equal moral standing, but something lethal to the survival of Hutus. Such toxicity was described to be inextricable to each Tutsi and is epitomised in a March 1993 Kangura article: "A cockroach cannot give birth to a butterfly. It is true. A cockroach gives birth to another cockroach... the history of Rwanda shows us clearly that a Tutsi stays always exactly the same that he has never changed... They are all linked...their evilness in 
the same." ${ }^{87}$ Toxification of this kind was unabatedly dispersed throughout Rwanda prior to the 1994 genocide. ${ }^{88}$ This language points to more than just allowing the mistreatment of individuals held to be sub- or less-than human; it signals the creation of a security dilemma in the minds of the perpetrators, wherein the exigencies of survival triumphed a zero-sum game: kill, or be killed. ${ }^{89}$ A Hutu perpetrator of the genocide articulated this perception: "we thought if we killed them all, they would not have the power to kill us." ${ }^{\prime 90}$ Another participant stated that the Tutsi "had become a threat greater than all we had experience together... That's how we reasoned and we killed at the time." ${ }^{\prime 91}$ This rhetoric illustrates the toxic to the self strain of toxification, which signals the genuine subscription to a kill before being killed logic held by perpetrators: it was, in the minds of the Hutu, "a war of self defense" ${ }^{92}$ against a toxic presence. This conviction in a group being held as toxic to the self can also account for individuals who do not join perpetrators ameliorating the toxic threat: for instance, Hutu extremists also murdered icyitso (accomplices) - that is, Hutu moderates who refused to partake in massacre, because (by not partaking in the extermination of the inyenzi) they were seen to be allowing Tutsis to continue posing a toxic threat to every other Hutu. Consequently, by way of Tutsi complicity and sympathy, Hutu moderates were branded as equally lethal and eliminated as such. ${ }^{93}$ In sum, the dehumanization of Tutsis as omnipresent and Unwanzi ni umwe ni umusti (the enemy is one) played an unequivocal role in grooming perpetrators for carnage by no longer regarding the Tutsis as human, thereby numbing the abhorrence to killing fellow humans and regarding it as more tolerable. ${ }^{94}$ The purpose of this review of the Rwandan genocide, however, was to illustrate the concept of toxification as toxic to the self-something which sits as distinct from dehumanization. This toxic rhetoric moved beyond seeing killing as allowable, and suggests that -in the eyes of the Hutu extremists - there was "no alternative but to annihilate ${ }^{\prime \prime 5}$ the Tutsi in their entirety. ${ }^{96}$

\section{Other Cases that Illustrate Toxification}

The above illustrative examples were included to demonstrate how toxification can be understood in practice. The selection of the Holocaust and 1994 Rwandan genocide was on the basis that they best illustrate toxification in practice; it is however appropriate to give brief attention to other twentieth century genocides so as to flag toxification is not specific to these instances. For example, in the context of the Armenian genocide, Pan-Turkish propagandists described Armenians as "invasive infection in Muslim Turkish society" ${ }^{97}$ and "parasites outside the confines of his homeland, sucking off the marrow of the people of the host country, ${ }^{\prime 98}$ before moving onto another host country. ${ }^{99}$ In 1915, Rear Admiral Wilhelm Souchon stated: "It will be salvation for Turkey when it has done away with the last Armenian; it will then be rid of subversive bloodsuckers." ${ }^{100}$ Likewise, Mehmed Reshid-a then Turkish physician and later the governor of Diyarbekir-apparently asked rhetorically "Isn't it the duty of a doctor to destroy these microbes?"101

Further illustrating toxic to the ideal, the Cambodian genocide has clear rhetoric that moves beyond marking difference-us versus them-and dehumanization. As Hinton identifies, "the goal of the Khmer Rouge was, as one Khmer saying held, 'to completely annihilate diseases of consciousness'," 102 that is, to exterminate those "hidden enemies burrowing from within" 103 who Pol Pot regarded as having a "sickness of consciousness"104 that was toxic to the Great Leap Forward, the utopia as desired by the Khmer Rouge perpetrators. The inclusion of these brief (and, indeed, shallow) engagements with alternative twentieth century genocides was to demonstrate that toxification is by no means distinct to the Holocaust and Rwanda. However, further robust empirical studies are needed to demonstrate conclusively that toxification is a more telling early warning sign for genocide than dehumanization.

\section{Conclusion}

Dehumanization is often considered to be an alarming early warning sign for genocide. However, while the definition of dehumanization is consistent across genocide and broader dehumanization literature, a broader literature review unveils that dehumanization occurs in a variety of instancesmany of which occur in everyday, social interaction that do not lead to, or are associated with violence or conflict. Accordingly, although dehumanization plays a role in grooming perpetrators into believing discrimination, violence and killing particular individuals is permissible because 
they are no longer human, a more indicative early warning sign is one that articulates when killing is seen by the perpetrators as a necessity. This paper is an emerging research agenda that offers toxification as such an early warning. Toxification refers to the cognitive perception of the target group as not merely inhuman, but as toxic to the self, or toxic to the ideal; consequently, the victim group must be purged for the security the perpetrators' society. Whereas dehumanization suggests that slaughtering certain individuals may be tolerable, I submit that toxification perhaps points to the more sinister process specific to genocide - that is, the necessity to kill. The purpose here was to simply introduce the concept of toxification and enhance the reader's understanding of how the concept can work in practice by looking to two twentieth century genocides as the main illustrative examples, and giving brief attention to two additional cases. This lays the foundations for more robust empirical studies that examine other genocides for similar rhetoric, and begin to answer the question posed in the title of this paper. By providing an emerging research agenda into the complexities of dehumanization as an early warning sign for genocide and offering toxification as perhaps a better alternative, I hope to have contributed one more piece to the perplexing puzzle that is the prevention of genocide.

\section{Acknowledgments}

I would like to thank Stephen McLoughlin for his immeasurable guidance throughout the development of this paper. I would also like to thank my two most important and special supporters, Paul and Corinne Neilsen, for their unwavering commitment to me and 'toxification'. This paper was presented at the eleventh annual International Association of Genocide Scholars conference in Winnipeg, Canada in July 2014.

\section{Endnotes}

1 Manus Midlarsky, The Killing Trap: Genocide in the Twentieth Century (Cambridge: Cambridge University Press, 2005), 7. http://dx.doi.org/10.1017/CBO9780511491023

2 These early warning signs aim to alert governments of forthcoming mass atrocities, and position such bodies to make timely, informed decisions about response prior to the onset of genocide. While there is no overarching synthesis of all early warning signs, widely accepted genocide indicia include exclusionary ideologies, past genocides or violence, weak economy and governance, governments transitioning toward democracy, authoritarian regimes, and socio-psychological influences. For more genocide early warnings, including dehumanization, see Stephen McLoughlin, The Structural Prevention of Mass Atrocities: Understanding Risk and Resilience (New York: Routledge, 2014); Barbara Harff, "No Lessons Learned from the Holocaust? Assessing Risks of Genocide and Political Mass Murder since 1955," American Political Science Review 97, 1 (2003): 57-73; Henry Huttenbach, "From the Editor: Earlier Early Warning Signs," Journal of Genocide Research 5, 4 (2003): 501-502; Jonathan Whittall, "Humanitarian Early Warning Systems: Myth and Reality," Third World Quarterly 31, 8 (2011): 1237-1250; William Donohue, "The Identity Trap: Managing Paradox in Crisis Bargaining," in The Slippery Slope to Genocide: Reducing Identity Conflicts and Preventing Mass Murder, ed. William Zartman, Mark Anstey and Paul Meerts (Oxford: Oxford University Press, 2012), 55-71; Kurt Jonassohn and Karin Björnson, Genocide and Gross Human Rights Violations (New Brunswick: Transaction Publications, 1999); David Moshman, "Us and Them: Identity and Genocide," An International Journal of Theory and Research 7, 2 (2007): 115-135; David Hamburg, Preventing Genocide: Practical Steps Toward Early Detection and Effective Action (London: Paradigm Publishers, 2008); Irving Horowitz, Taking Lives: Genocide and State Power (New Brunswick: Transaction Publishers, 1997).

3 Toni Erskine, Embedded Cosmopolitanism:Duties to Strangers and Enemies in a World of "Dislocated Communities." (Oxford: Oxford University Press, 2008), 40. http://dx.doi.org/10.5871/bacad/9780197264379.001.0001

4 Nick Haslam, et al., "Dehumanization: A New Perspective," Social and Personality Psychology Compass 1, 1 (2007): 409-422, 409, 420; Tendayi Viki, Daniel Osgood and Sabine Phillips, "Dehumanization and Selfreported Proclivity to Torture Prisoners of War," Journal of Experimental Social Psychology 49, 1 (2013): 325328; Joris Lammers and Diedrick Stapel, "Power increases Dehumanization," Group Processes Intergroup Relations 14, 1 (2011): 113- 126; Emanuele Castano and Miroslaw Kofta, "Dehumanization: Humanity and its Denial," Group Processes and Intergroup Relations 12, 6 (2009): 695-707,

5 Gregory Stanton, "Could the Rwandan Genocide Have Been Prevented?" Journal of Genocide Research 6, 2 (2004): 211-228, 214.

6 Thereby blurring the crucial aforesaid distinction between the killing of individuals being more permissible (because they are no longer deserving of the same moral standing as humans), and being a necessity. 
7 On this point, Timothy Williams and myself are conducting a statistical analysis of toxification in genocide and non-genocide cases in the post-1955 era to determine the extent to which it can be considered a telling early warning sign for genocide. This paper will be presented at the $12^{\text {th }}$ International Association of Genocide Scholars Conference in Yerevan, Armenia of 2015. Specifically, the paper tests toxification as an independent variable that signals forthcoming genocides in a cross-spacial and cross-temporal comparison. Building on existing structural models and using political instability as defined by the Political Instability Task Force (PITF) as the unit of analysis, the article empirically tests the impact of toxification as an antecedent that flags latent genocides. The paper will gauge the empirical impact of toxification vis-à-vis other factors, including - but not limited to-the degree of democratization, other ideologies, state capacity, warfare, ethnicity, economic interdependence, and political upheaval, running a logistical regression analysis of post-Second World War genocides, and high-risk cases in which genocide did not occur from the years 1955 to 2013.

8 I do not wish to refute the accuracy or relevance of other, accepted early warning signs. Instead, I am simply seeking to highlight the insufficiency of dehumanization as an alarming early warning sign for genocide, and, by extension, open discussions that can lead to a more rigorous early warning framework.

9 Again, this is not to support the argument that toxification is a more indicative early warning sign for genocide, as this is not the point here. It is simply to show that such rhetoric does exist outside the two main illustrative examples.

10 Susan Opotow, “Moral Exclusion and Injustice: An Introduction," Journal of Social Issues, 46, 1 (1990): 1-20, 1.

11 For more research on dehumanization and its various consequences, see Phillip Goff, et al., "Not Yet Human: Implicit Knowledge, Historical Dehumanization, and Contemporary Consequences," Journal of Personality and Social Psychology 94, 1 (2008): 292-306; Victoria Esses, et al., "Justice, Morality and the Dehumanization of Refugees," Social Justice Research 21 (2008): 4-25; Louis Winnifred, Victoria Esses and Richard Lalonde, "National Identification, Perceived Threat, and Dehumanization as Antecedents of Negative Attitudes Towards Immigrants in Australia and Canada," Journal of Applied Social Science 43 (2013): 156-165; Laurie Rudman and Kris Mescher, "Of Animals and Objects: Men's implicit Dehumanization of Women and the Likelihood of Sexual Aggression," Personality and Social Psychology Bulletin 38, 6 (2012): 734-746; Samera Esmeir, “On Making Dehumanization Possible," Modern Language Association 121, 5 (2006): 1544-1551; Heather Keith and Kenneth Keith, Intellectual Disability: Ethics, Dehumanization and a New Moral Community (Oxford: John Wiley \& Sons, Inc., 2013); Lisa Haagensen and Marnix Croes, “Thy Brother's Keeper?: The Relationship between Social Distance and Intensity of Dehumanization During Genocide," Genocide Studies and Prevention 7, 2 (2012): 223-250, 225; Leo Kuper, Genocide: Its Political Uses in the Twentieth Century (New Haven: Yale University Press, 1982), 86.

12 Original italics, Israel Charny, "Dehumanization-'Killing' the Humanity of Another," in Encyclopedia of Genocide, ed. Israel Charny (California: ABC-CLIO, 1999), 155-159, 155.

13 Helen Fein, Accounting for Genocide (New York: The Free Press, 1979), 4.

14 Herbert Kelman, "Violence without Moral Restraint: Reflections on the Dehumanizations of Victims and Victimizers," Journal of Social Issues 29, 4 (1973): 25-37, 43. http://dx.doi.org/10.1111/j.1540-4560.1973. tb00102.x

15 Tobias Greitemeyer and Neil McLatchie, “Denying Humanness to Others: a Newly Discovered Mechanism by which Violent Video Games Increase Aggressive Behavior," Psychological Science, 22, 5 (2011): 659-656, $661,663$.

16 Haslam, et al., "Dehumanization," 414.

17 Haslam, et al., "Dehumanization," 413-414.

18 Kelman, "Violence without Moral Restraint," 48; Esses, et al., "Justice, Morality and the Dehumanization of Refugees," 6-7; Haslam, et al., "Dehumanization," 413.

19 Omar Haque and Adam Waytz, "Dehumanization in Medicine: Causes, Solutions and Functions," Perspectives on Psychological Science 7, 2 (2012): 176-186, 177.

20 Haque and Waytz, "Dehumanization in Medicine”, 177.

21 Susan Fiske, "From Dehumanization and Objectification to Rehumanization: Neuroimaging Studies on the Building Blocks of Empathy," Values, Empathy and Fairness across Social Barriers, 1167, (2009): 31-34; Lasana Harris and Susan Fiske, "Dehumanising the Lowest of the Low: Neuroimaging Responses to Extreme Outgroups," Psychological Science 17 (2006): 847-853.

22 Farhad Dalal, "Racism: Processes of Detachment, Dehumanization, and Hatred," Psychoanalytic Quarterly 75, 1 (2006): 131-161, 158.

23 Haque and Waytz, "Dehumanization in Medicine," 178. 
24 Gregory Stanton, “The Eight Stages of Genocide," Genocide Watch, http://www.genocidewatch.org/ aboutgenocide/8stagesofgenocide.html. Accessed 30 June 2013.

25 Jacques Sémelin, Purify and Destroy: The Political Uses of Massacre and Genocide (New York: Columbia University Press, 2007), 39, 49, 297; Graham C. Kinloch, "The Possible Causes and Reduction of Genocide," in Genocide: Approaches, Case Studies and Responses, eds. Graham Kinloch and Raj Mohan (New York: Algora Publishing, 2005), 15-32, 17; Haagensen and Croes, “Thy Brother's Keeper?" 225; Kelman, "Violence without Moral Restraint," 49; Herbert Hirsch, Genocide and the Politics of Memory: Studying Death to Preserve Life (North Carolina: University of North Carolina Press, 1995), 101-102.

26 Stanton, “Could the Rwandan Genocide Have Been Prevented?", 214.

27 Sémelin, Purify and Destroy, 39.

28 Alexander Hinton, Why Did They Kill? Cambodia in the Shadow of Genocide (Berkley: University of California Press, 2005), 284-285.

29 United Nations News Centre, “Genocide Begins with 'Dehumanization': No Single Country is Immune From Risk, Warns UN Official," (2014), UN News Centre, http://www.un.org/apps/news/ story.asp?NewsID=49556. Accessed 3 March 2015. For more discussions regarding the importance of dehumanization as an early warning sign for genocide, see Kuper, Genocide; Midlarsky, The Killing Trap, 99; Hamburg, Preventing Genocide, 22; Ervin Staub, "The Roots and Prevention of Genocide and Related Mass Violence," in The Slippery Slope to Genocide: Reducing Identity Conflicts and Preventing Mass Murder, eds. William Zartman, Mark Anstey and Paul Meerts (Oxford: Oxford University Press, 2012), 35-52, 39; Donohue, "The Identity Trap," 55; Benjamin Valentino, Final Solutions: Mass Killing and Genocide in the $20^{\text {th }}$ Century (New York: Cornell University Press, 2004).

30 That is, historical, sociological, psychological, anthropological and political scientist studies that concern dehumanization but not in relation to genocide.

31 Rico Martinez, Rosa Rodriquez-Bailon and Miguel Moya, "Are they Animals or Machines? Measuring Dehumanization," The Spanish Journal of Psychology 15, 3 (2012): 1110-1122; Caroline Tipler and Janet Ruscher, "Agency's Role in Dehumanization: Non-human Metaphors of Out-groups," Social and Personal Psychology Compass 8, 5 (2014): 214-248, 219, 223; Castano and Kofta, "Dehumanization: Humanity and its Denial"; Haslam, et al., "Dehumanization"; Rowan Savage, "Disease Incarnate: Biological Discourse and Genocidal Dehumanization in the Age of Modernity," Journal of Historical Sociology 20, 3 (2007): 404-440Lammers and Stapel, "Power Increases Dehumanization"; Goff et al., "Not Yet Human"; Keith and Keith, Intellectual Disability.

32 Haslam et al., "Dehumanization," 410.

33 Haslam et al., “Dehumanization,” 420.

34 Rudman and Mescher, "Of Animals and Objects," 734-746.

35 Harris and Fiske, “Dehumanising the Lowest of the Low," 852; Fiske, “From Dehumanization,” 32.

36 James Waller, Becoming Evil: How Ordinary People Commit Genocide and Mass Killing (Oxford: Oxford University Press, 2007), 296-297. For a similar contribution, see Christopher Powell, Barbaric Civilisation: A Critical Sociology of Genocide (London: McGill-Queen's University Press, 2011).

37 For additional research regarding the dehumanization of people with intellectual impairments as being vegetables, see Tipler and Ruscher, "Agency's Role in Dehumanization," 214-248.

38 Goff, et al. “Not Yet Human,” 293.

39 Esses, et al., "Justice, Morality and the Dehumanization of Refugees," 4-25; Louis, Esses and Lalonde, "National Identification," 156.

40 Haslam et al., "Dehumanization," 420.

41 And so their experiences are not to be devalued or posited as less-intolerable.

42 Viki, Osgood and Phillips, "Dehumanization and Self-Reported Proclivity to Torture," 325; Haslam et al., "Dehumanization," 420; Tipler and Ruscher, "Agency's Role in Dehumanization," 217.

43 Lammers and Stapel, "Power increases Dehumanization," 116; Tipler and Ruscher, “Agency's Role in Dehumanization," 217; Haslam, et al. "Dehumanization," 423; Karen Stollznow, "Dehumanization in Language and Thought," Journal of Language and Politics 7, 2 (2008): 177-200, 178.

44 Savage, “Disease Incarnate," 405.

45 Rowan Savage, "Vermin to be Cleared off the Face of the Earth: Perpetrator Representations of Genocide Victims as Animals," in Genocide Perspectives III: Essay on the Holocaust and other Genocides, eds. Colin Tatz, Peter Arnold and Sandra Tatz (Sydney: Brandl \& Schlesinger, 2006), 1-32, 21.

46 Waller, Becoming Evil, 245. 
47 Original italics, Charny, "Dehumanization-'killing' the Humanity of Another," 156.

48 Johannes Lang, "Questioning Dehumanization: Intersubjective Dimensions of Violence in the Nazi Concentration and Death Camps," Holocaust and Genocide Studies 24, 5 (2010): 228.

49 For instance, instead of focusing on explicit dehumanization, Jacques-Philippe Leyes and colleagues introduce the concept of infra-humanization. Infra-humanization is the process of assigning more humanity to one's self and in-group than to members of the out-group; as a consequence, members of the out-group are implicitly ascribed less humanity. For more information on degrees of dehumanization, see Jacques-Philippe Leyens, Paola M. Paladino, Ramon Rodriquez-Torres, Jeroen Vaes, et al., "The Emotional Side of Prejudice: The Attribution of Uniquely Human Emotions to Ingroups and Outgroups," Personality and Social Psychology Review 4, 2 (2000): 395-411186-197; Naria Delgado, Armanda Rodriquez-Perez, Jeroen Vaes, Jacques-Philippe Leyens and Veronica Betancor, "Priming Effects of Violence on Infrahumanization," Group Processes and Intergroup Relations 12, 6, (2009): 699-714, 700; Paul Bain, Joonha Park, Christopher Kwok, and Nick Haslam, "Attributing Human Uniqueness and Human Nature to Cultural Groups: Distinct forms of Subtle Dehumanization," Group Processes and Intergroup Relations 12, 6, (2009): 789-805; and Nick Haslam, Yoshihisa Kashima, Stephen Loughnan, Junqi Shi, and Caterina Suitner, "Subhuman, Inhuman and Superhuman: Contrasting Humans with Nonhumans in Three Cultures," Social Cognition 26, 2 (2008): 248-258.

50 Michael J. Shapiro, "Ethics of Encounter: Unreading, Unmapping the Imperium," in Moral Spaces: Rethinking Ethics and World Politics, eds. David Campbell and Michael J. Shapiro. (Minneapolis: University of Minnesota Press, 1999), 57-90, 77.

51 Shapiro, "Ethics of Encounter," 80.

52 Shapiro, “Ethics of Encounter," 64.

53 Julia Kristeva, Powers of Horror: An Essay on Abjection (New York: Columbia University Press, 1982).

54 Mary Douglas, Purity and Danger: An Analysis of the Concepts of Pollution and Taboo (London: Routledge and Kegan Paul, 1966), 40. http://dx.doi.org/10.4324/9780203361832

55 Douglas, Purity and Danger, 2.

56 Douglas, Purity and Danger, 41, 95.

57 Douglas, Purity and Danger, 36, 165.

58 Douglas, Purity and Danger, 2.

59 Douglas, Purity and Danger, 6.

60 William Hewitt, Defining the Horrific: Readings on Genocide and Holocaust in the Twentieth Century (New Jersey: Pearson, 2004), 47.

61 Hewitt, Defining the Horrific, 47.

62 Alexander Alvarez, "Adjusting to Genocide: The Techniques of Neutralisation and the Holocaust," Social Science History 21, 2 (1997): 139-178; Daniele Conversi, "Genocide, Ethnic Cleansing and Nationalism," in The Sage Handbook of Nations and Nationalism, eds. Gerard Delanty and Krishan Kumer (London: Sage Publications, 2006), 320-333, 328; Kinloch, “The Possible Causes and Reduction of Genocide," 18; Valentino, Final Solutions, 47, 235; Jonassohn and Björnson, Genocide.

63 Savage, "Vermin," 27. At the very least, perpetrators often become indifferent to killing, influenced by obedience to authorities, or act out of fear of the consequences of non-compliance.

64 Scott Straus, The Order of Genocide: Race, Power and War in Rwanda (New York: Cornell University, 2006), 228.

65 This manifestation of toxification is marked by modernity and the glorification of science, reason and rationality. It draws upon the linear evolution and perfectibility of humans, wherein some humans ought to be erased because they were stagnating or regressing the advancement of humanity. For discussions on victims being regarded as lethal or dangerous to the body politic, see Eric Markusen, "Genocide and Total War: A Preliminary Comparison," in Genocide and the Modern Age, eds. Isidor Wallimann and Michael Dobkowski (Syracuse: Syracuse University Press, 2000), 97-123; Colin Tatz, With Intent to Destroy (London: Verso, 2003); Zygmunt Bauman, Modernity and the Holocaust (Cambridge: Polity Press, 1989), 17; Hamburg, Preventing Genocide, 31; Savage, "Disease Incarnate," 408, 411; Kelman, "Violence without Moral Restraint," 33; Hinton, Why Did They Kill?, 282.

66 Marie Fleming, "Genocide and the Body Politic in the Time of Modernity," in The Specter of Genocide: Mass Murder in Historical Perspective, eds. Robert Gellately and Ben Kiernan (Cambridge: Cambridge University Press, 2003): 97-114, 112-113; Sémelin, Purify and Destroy, 35; Andreas Musolff, Metaphor, Nation and the Holocaust: The Concept of Body Politic (New York: Routledge, 2010), 3; Kelman, "Violence without Moral Restraint," 33; Colin Tatz, "The Doctorhood of Genocide" in Genocide Perspectives III, eds. Colin Tatz, Peter Arnold and Sandra Tatz (Sydney: Brandl \& Schlesinger, 2006): 78-94; Moshman, “Us and Them," 123. 
67 Susan Sontag, “Disease as a Political Metaphor," New York Review of Books 1, 1 (1978): 18; Savage, "Disease Incarnate," 419, 430.

68 Thus, and as stated previously, the purpose of this paper is not to prove that toxification is a more indicative early warning sign than dehumanization, as this would require greater breadth of empirical investigation that falls beyond the scope of this paper and is best suited for research once the concept is better understood. Rather, this article offers an embryonic conceptual framework that offers toxification as a coherent concept that articulates when a victim is thought to be lethal to the would-be perpetrators - as perhaps a more viable alternative to dehumanization.

69 Eric Weitz, A Century of Genocide: Utopias of Race and Nation (Princeton University Press: Princeton, 2003), 107; Moshman, "Us and Them," 128-129; Fleming, "Genocide and the Body Politic," 113; Savage, "Disease Incarnate," 426; Raul Hilberg, The Destruction of the European Jews (New York: Holmes and Meier, 1985), 12; Hamburg, Preventing Genocide, 35.

70 William Rubinstein, Genocide: A History (London: Pearson, 2004), 187; Weitz, A Century of Genocide, 119.

71 Bauman, Modernity and the Holocaust, 17; Hamburg, Preventing Genocide, 42; Valentino, Final Solutions, 191; Sémelin, Purify and Destroy, 34; Rubinstein, Genocide, 175, 184.

72 That is, officials and party representatives of the Nazi party: individuals who worked within the Nazi party, particularly those members in the higher echelons of command responsible for conditioning the public perception of Jewish people, such as Joseph Goebbels, the minister of propaganda and enlightenment, and other political and military figures who regularly delivered speeches to the German public regarding the Jewish presence and the need for their destruction.

73 My use of German here is to refer to those individuals in the population who the Nazi regime and ideology regarded as a true German (that is, a German who did not fall into the undesirable categories listed above, and was not a Jewish sympathizer). These individuals were the primary target audience of Nazi propaganda.

74 Richard Weikart, From Darwin to Hitler: Evolutionary Ethics, Eugenics and Racism in Germany (New York: Palgrave Macmillan, 2004), 55; Savage, “Disease Incarnate," 413.

75 Musolff, Metaphor, Nation and the Holocaust, 35.

76 Midlarsky, The Killing Trap, 217; Hilberg, The Destruction of the European Jews, 102; Musolff, Metaphor, Nation and the Holocaust, 25; Hirsch, Genocide and the Politics of Memory, 102; Tatz, With Intent to Destroy, 40-41; Savage, "Disease Incarnate," 415.

77 James K. Mason and Philip Fielden. Republic to Reich: A History of Germany, 1918-1939 (North Ryde: McGraw Hill, 2007), 197; Stefan Berger, Inventing the Nation: Germany (Oxford: Oxford University Press, 2004), 139; Sémelin, Purify and Destory, 47; Midlarsky, The Killing Trap, 52-53; Savage, "Disease Incarnate," 410; Tatz, "The Doctorhood of Genocide," 40-41; Musolff, Metaphor, Nation and the Holocaust, 1-3, 130.

78 Weitz, A Century of Genocide, 106.

79 Berger, Inventing the Nation, 144.

80 Ernst Hiemer, "Der Giftpilz, published by Julius Streicher", (1938) https://scholar.vt.edu/access/content/ user/hokie05/Lesson\%20Plans/Worksheets/Poisonous\%20Mushroom\%20stories\%20and\%20questions. pdf. Accessed 5 July 2013; Carmelo Lisciotto, “Nazi Propaganda” (2009), Holocaust Education and Archive Research Team, http://www.holocaustresearchproject.org/holoprelude/nazprop.html. Accessed 5 July 2013.

81 Valentino, Final Solutions, 191; Sémelin, Purify and Destroy, 46; Conversi, “Genocide, Ethnic Cleansing and Nationalism," 320; Midlarsky, The Killing Trap, 35-36, 74; Bauman, Modernity and the Holocaust, 15, 18; Fein, Accounting for Genocide, 26, 29; Musolff, Metaphor, Nation and the Holocaust, 35; Staub, "The Roots and Prevention," 38; Moshman, "Us and Them," 123; Savage, "Disease Incarnate," 412-413.

82 Statements from Joseph Goebbels, Reich Minister of Propaganda in Nazi Germany from 1933 to 1945 , further help us understand how toxification manifests. He articulated not only the fact that Jewish people were seen as infectious ulcers that had to be lacerated, but the urgency with which it must be done: "our task here is surgical...drastic incision or some day Europe will perish of the Jewish disease." Quote from Savage, "Disease Incarnate," 421, 423. See also, David Welch, "Nazi Propaganda and the Volksgemeinschaft: Constructing a People's Community," Contemporary History Understanding of Nazi Germany 39, 2 (2004), 213238; Annie McCallum, Germany 1918-1945: Democracy to Dictatorship (Port Melbourne: Reed International Books Pty Ltd, 1992), 79; Douglas Newton, Germany 1918-1945: From Days of Hope to Years of Horror (Melbourne: Collin Dove, 1990), 227.

83 Tatz, "The Doctorhood of Genocide," 89

84 Tatz, "The Doctorhood of Genocide," 89.

85 Savage, “Disease Incarnate," 426. 
86 Mahmood Mamdani, When the Victims Became Killers: Colonialism, Nativism, and the Genocide in Rwanda (New Jersey: Princeton University Press, 2001), 14-16; Linda Melvern, Conspiracy to Murder: The Rwandan Genocide (London: Verso, 2004), 8; Jean Mukimbiri, Jean, "The Seven Stages of the Rwandan Genocide," Journal of International Criminal Justice 3 (2005): 823-836, 829; Janine Clark, "Learning from the Past: Three Lessons from the Rwandan Genocide," African Studies 68, 1, (2009): 1-28, 7; Stanton, "Could the Rwandan genocide been prevented?", 214.

87 Valentino, Final Solutions, 185.

88 Melvern, Conspiracy to Murder, 8-9; Mamdani, When the Victims Became Killers, 9, 32; Bill Berkeley, "Road to Genocide," in The New Killing Fields: Massacre and the Politics of Intervention, eds. Nicolaus Mills and Kira Brunner (New York: Basic Books, 2002), 103-116, 110.

89 Berkeley, "Road to Genocide," 111-112; René Lemarchand, “The 1994 Rwanda Genocide” in Century of Genocide: Critical Essays and Eyewitness Accounts, eds. Samuel Totten and William Parsons (New York: Routledge, 2009), 483-504, 491; Valentino, Final Solutions, 186.

90 Scott Straus, The Order of Genocide: Race, Power and War in Rwanda (Ithaca: Cornell University Press, 2006), 160.

91 Straus, The Order of Genocide, 113.

92 Sémelin, Purify and Destroy, 249.

93 Moshman, “Us and Them," 130; Savage, “Disease Incarnate," 41.

94 Straus, The Order of Genocide, 173; Sémelin, Purify and Destroy, 257; Clark, "Learning from the Past," 7; Mukimbiri, "The Seven Stages," 829.

95 Lemarchand, “The 1994 Rwanda Genocide," 491.

96 Valentino, Final Solutions, 181-183, 186; Melvern, Conspiracy to Murder, 8-9, 14; Mamdani, When the Victims Became Killers, 32; Berkeley, "Road to Genocide," 111.

97 Peter Balakian, The Burning Tigris: The Armenian Genocide and America's Response (New York: Harper Collins Publishers, 2003), 164.

98 Vahakn N.

99 See also Midlarsky, The Killing Trap, 217.

100 Quoted in Dadrian, The History of the Armenian Genocide, 263.

101 Balakian, The Burning Tigris, 164.

102 Hinton, Why Did They Kill?, 222.

103 Hinton, Why Did They Kill?, 218.

104 Hinton, Why Did They Kill?, 218. 